\title{
Falsification of Historical Figures (The Armenian Population in Turkey before and after the Genocide)
}

\author{
Gaiane Muradian \\ Yerevan State University
}

\begin{abstract}
The argument and objective of the present case study is to prove, through the scientific method of analysis, that the online news medium Azerbaijani Vision (en.azvision.az), applying history falsification (negationism and revisionism) referring to the 1915 Armenian Genocide in general, and to the historic figures on the number of Ottoman Armenian population before and after the Genocide in particular, leverages technology to produce and disseminate false and fabricated figures about the mentioned data of Armenian population within the frames of its anti-Armenian propaganda. My assumption will be that the false model of history serves its function for a certain while because societies eventually enter a period when distorted representations stop serving the intended ends and impartial and unbiased research starts seeking the truth.
\end{abstract}

Key words: Anti-Armenian propaganda, historical negationism and revisionism, falsification of historical data, news media, Ottoman Armenians, population number.

\section{Introduction}

Truth is important, concealing historical truth is dishonest and destructive, but far worse is when it is lied about to make into propaganda. In totalitarian societies truth is found not in objective principles about the present and the past, but in certain desired aims and purposes, which, when already set, start to propagate the "invented" truth. In such cases - to propagate the false truth - all 
other forms and modes of information are tailored through the application of different manipulative techniques. "Reason is henceforth thrown out the window and the state's version of truth is beyond contestation" (Hunter 2017). This means that a series of propaganda tactics (linguistic and psychological manipulation, logical fallacies, distortion of facts, data and figures, outright deception) which create an argument that favours a particular interest - are involved to suppress the true information channels and induce people to believe in the falsely created truth or just distract their attention on the assumption that the public has a limited attention span.

Public opinion expresses itself through channels which are provided by the mass media of communication - without which there could be no propaganda (Ellul 1973). Today, as a part of mass media, social media too is involved not only in sharing true information but also in making new attempts to serve dishonest propagative ends and accomplish certain political objectives. In relation to Armenia and the Armenian Genocide, this is at large practised through falsification of history: through historical negationism and revisionism, i.e. distortion and reinterpretation of historic record, historical facts, events, data and figures.

Thus, the present case study will focus on history falsification (negationism and revisionism) referring to the 1915 Armenian Genocide in general, and on the falsification of historic figures on the number of Ottoman Armenian population before and after the Genocide in particular. The falsified data belong to Azerbaijani Vision (<en.azvision.az>) news medium which leverages technology to produce and disseminate false figures within the frames of its anti-Armenian propaganda.

\section{Historical Negationism and Revisionism}

The implied objective of this line of thought is a nightmare world in which the Leader, or some other clique, controls not only the future but also the past [...]. This prospect frightens me much more than bombs.

(Orwell 1943) 
Historical negationism and revisionism are indispensable elements of history falsification. Falsification of history denotes to the deliberate change of the course of history by altering past historical facts, events, data and figures through information intervention, manipulative propaganda tools and techniques. The aim is to erase people's recollection of the previous timeline to achieve certain political gains. The falsifiers know quite well that the ideological basis of a nation, culture, identity is the historical memory and historical consciousness without which the entity will fall apart. This is the direct objective of the so-called information warfare of Turkey and Azerbaijan against Armenia and Armenians.

There were roughly 2,100,000 Armenians in the declining Ottoman Empire on the eve of World War I and before the 1915 Armenian Genocide (Redgate 1998:271; University of Minnesota Center for Holocaust \& Genocide Studies 2019). By 1922, there were fewer than 400,000 (ibid.) Up to 1.5 million were killed in one of the most flagrant mass violations of human rights in modern history. This massacre was a contributing factor to Hitler's extermination of the Jews of Europe a quarter of a century later. Yet, Turkey does not accept the fact of the Genocide. It recognises killings as a consequence of WWI, despite the opposing views by modern research, that ethnic Armenians were systematically targeted, and it continues its information warfare to date. Now, Azerbaijan has joined in this battle presenting new examples of historical negationism and revisionism.

Historical negationism/denialism ${ }^{1}$ denotes not only the distortion of the historical record but also a legitimate academic pursuit of reinterpretation of the historical record and questioning of the accepted views (Ravetto 2001:33; Historical Negationism 2019). It also "rejects the entire foundation of historical evidence" (Berger 2002:154). In its attempt to revise the past, it uses techniques inadmissible in proper historical discourse, i.e.

(1) presents forged documents as genuine,

(2) invents ingenious but implausible reasons for distrusting genuine documents,

(3) attributes conclusions to books and sources that report the opposite, 
(4) manipulates statistical series to support the given point of view, and

(5) deliberately mistranslates texts (Evans 2001:145).

Examples of negationism are the denials of the Holocaust, the Armenian Genocide, the Soviet crimes, the Japanese war crime, etc. Today negationism, referring to the mentioned crimes, is spread far and large via the new technological media.

The purpose of historical negationism is to achieve a national or political aim (with the consent of the government) by providing an illusion, a myth of positiveness at the expense of the so-called "enemy" thus controlling not only the ideological but also the political influence. Often the purpose is to present a consciously-falsified or distorted interpretation of the past so that it can serve partisan or ideological purposes in the present (McPherson 2003). To achieve this, deception and denial are practised: information is falsified, truth is obscured, public opinion is manipulated, a revised historical event, data or figure is discussed, certain documented information is protected from being shared with others. Article 301 of the Turkish Penal Code is a good example of legalized historical negationism. ${ }^{2}$ Turkish history textbooks and other sources referring to the Armenian Genocide as a lie (claiming that Armenians were relocated to prevent them from attacking Turkish citizens) is an excellent example of history falsification. As to Azerbaijan, different authors (Schnirelmann 2001:196-197; Hewsen 2001:39; Bournoutian 2009:8-14) have stated that since 1960s its historical negationism is demonstrated in removing primary historical sources on the South Caucasus including any mention of Armenians, replacing the word Armenian by Albanian. The mentioned and many other forms of history falsification are applied to create an impression that historically there was no Armenian presence in the territory.

Historical revisionism identifies the reinterpretation of the historical record. It usually means challenging the established, accepted or traditional views and older moral judgements held by professional scholars about a historical event, data, figure, and introducing contrary evidence or reinterpreting the motivations and decisions of the people involved (Historical Revisionism 2019). At a basic level, true judgements are depicted as false and 
negative, false conclusions are added to books, statistical data is manipulated, and texts are deliberately mistranslated. The use of forged documents and neglect of genuine sources turn historical revisionism into historical negationism. This is especially the case when historical revisionism is applied to the Armenian Genocide denial. For example, according to T. Akčam (2014) in Turkish history textbooks the revisionists claim that Armenians killed 600,000 Turks, that the deportations were organized to save Armenians from furious Armenian gangs, that the displaced Armenians were able to return to Turkey and reclaim their properties.

A vivid case in point - the history falsification (both history negation and history revision) in general and falsification of figures in particular - is the English language online paper of 15 May 2017 of Azerbaijani Vision (en.azvision.az) entitled Is University of Minnesota aware of Mathematics? which will be discussed below.

\section{The Number of Ottoman Armenians before and after the Genocide}

The falsification of the past is a rather common phenomenon inherent in Azerbaijani research and media publications (including modern technology media) today. An obvious, intentional, blatant and premeditated falsification referring to the Armenian Genocide is in full swing as well.

The above mentioned publication of Azerbaijani Vision contains evident false information and represents a clear distortion of historical data - distortion of historical figures referring to the number of Ottoman Armenians before and after the Genocide, to be more exact. The general narrative scheme the unknown author or authors employ in their falsification exercise relates to the following table of data presented in the history section of the web portal of the University of Minnesota Center for Holocaust \& Genocide Studies. ${ }^{3}$ 


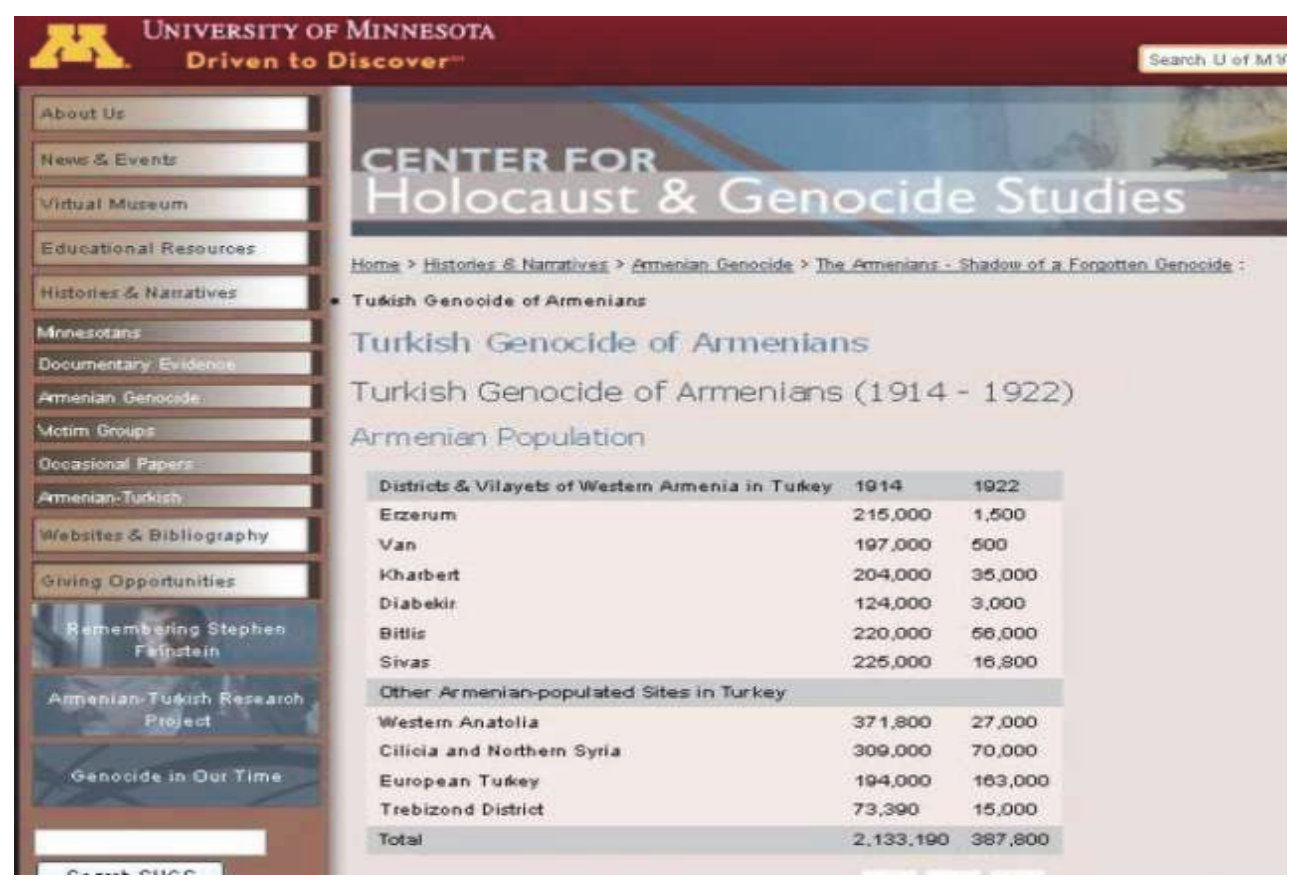

Criticising the University of Minnesota scholars, the unknown author(s) cite new figures and numbers which either fail to concur to the University's comparative data about the Ottoman Armenians in 1914 (before the Genocide) and in 1922 (after the Genocide), or contradict them explicitly.

Firstly, the medium - referring to the table and comparing the total figure of Ottoman Armenians before and after the Genocide (respectively 2,133,190 and 387,800$)$ - questions the number of the victims $(1,750,000)$ as well as the number of the Ottoman Armenians in 1922.

Establishing the exact size of the population is very important in determining an accurate estimation of Armenian losses between 1914 and 1922, and although this is a controversial topic, let us try to consider some statistics of Ottoman Armenian population in the mentioned period. At large, most estimates by Western scholars range from 1,500,000 to 2,400,000 or they just mention "more than two million". Most researchers (Kevorkian and Paboudjian 1992; Redgate 1998; McCarthy 2001) indicate the figures of $1,914,620$ or 2,100,000 for the entire Ottoman Armenian population in 1913-1914 (the figure 
is drawn from the Constantinople Armenian Patriarchate Statistics). In an interview to the Turkish newspaper Hurriyet of April 27, 1987, the Turkish historian Dr. Secil Akgun said, "The Ottomans do not have a definite number. That is, we have in our hands contradictory numbers regarding the Armenian population within the borders of the Ottoman Empire. [...] This is to be between two and three million."

While there is no clear consensus as to how many Armenians lost their lives during the Genocide and what followed, again there seems to be a consensus among Western scholars for the figure of $1,200,000$ to $1,500,000$ or "over one million" for the period between 1914 and 1922 or, as A. E Redgate (1992:272) states, despite varied estimates, it seems that about $1,000,000$ people were killed. German sources, most probably due to their access to murder sites (Germany was Ottoman Empire's ally then), gave the most exact and highest estimates of Armenian losses - 1,500,000 - on the basis of a report entitled Die Türkei (134/35, A18613) and addressed to the German foreign office in February 1916. The official Ottoman population statistics were often deliberately falsified to make the desired political point, hence the official statistics, compiled for the period between 1915 and 1918 (Ottoman Gazette 1920:3-4), mention only 800,000 killed. Moreover, this underestimated number originated from the bureau of Ahmed Djemal (Jemal Pasha) - the Ottoman military leader who was one of the main figures who initiated and carried out the Genocide. Thus, the figure of 800,000 seems to be fiction.

Considering numerous other factors and reasons which could have resulted in more deaths (of which there is ample evidence) during the mentioned period, and carrying out a mere superficial comparison of the above data, we can say that in 1922-1923 the Ottoman Armenian population in Turkey could not have been more than 400,000 .

The unknown reporter of Azerbaijani Vision questions not only the fact of the Genocide (using wording like so called Armenian Genocide, the place that forms the basis of the 'genocide' claims where supposedly Ottoman Armenians had been killed) but also the University of Minnesota figure of 387,800 . The medium presents its own viewpoint in text references indicating to the numbers 
486,000 and 624,000, and unethically blames the University of Minnesota scholars for deliberate inaccuracy (The first question that comes to mind is whether this table was prepared by an academical institution or not; Does the University of Minnesota know mathematics? They start taking calculus courses). Questioning the validity of the in text sources and checking all the references, I found out that not a single fact referring to the figures 486,000 and 624,000 is confirmed - the references are taken from a web paper entitled Tall Armenian Tale: 1.5 million genocide victims, lies vs archives (liveleack.com) - a one page material including the same in text references. Moreover, the rest of the Azerbaijani paper Is University of Minnesota aware of Mathematics? is an identical copy of the mentioned liveleack.com article (<https://www.liveleak.com/view?i=628_1439921546>).

Secondly, both the identical copy and the original claim that 250,000 or 300,000, or even 400,000 Armenians moved to Caucasus Armenia from Anatolia fighting illnesses and war conditions, 40,000 - to Iran, 70,000 - to South Russia, 20,000 - to Georgia. Adding to this the number 624,000 of Ottoman Armenians who remained in Turkey after the Genocide, the medium of information Azerbaijani Vision concludes: Without even questioning or examining the validity of the references of University of Minnesota, quoting the population of Ottoman Armenians as 2,133,190 in 1914, we conclude that 1,154,000 Ottoman Armenians were alive in 1921. All the reference sources to the above figures termed as official documents from US, British, Armenian and League of Nations archives and particularly as [U.K.FO 96/225]; Archives des Afferes Etrangeres de France, Serie Levant, Armenie; an official American document published in 1919; Mr. Lodge Washington Government Printing Office; National Geographic; Fridtjof Nansen-League of Nations, again redirected me to the twin article in liveleack.com with identical text references. What is more ridiculous, the authors of this "research paper" call others, the University of Minnesota Center for Holocaust \& Genocide Studies in particular, to prove the documents shown in their paper to be fake to avoid the powerless or weak position that many academical institutions have to go through because of their need for donations from different lobby groups. 
Thus, the above mentioned illiterate piece of writing of Azerbaijani Vision cannot be characterized otherwise than anti-Armenian propaganda, history falsification, negationism and revisionism. In addition, it is an evident case of plagiarism and scientific falsification; it goes against everything that the scientific method stands for. Such falsification and fabrication of evidence is an unethical and dangerous crime, and one of the worst misconducts that anyone in research community can commit.

\section{Conclusion}

Over the course of time, historical data can be wiped away into oblivion or not realize their social function. Moreover, political attitudes to the past may alter, and the past may drift into altogether different observational and interpretational context. However, the false model of history serves its function for a certain while because societies eventually enter a period when distorted representations stop serving the intended ends and impartial and unbiased research starts seeking the truth.

Today online media plays an important role in finding and sharing information, and engaging new audiences. To accomplish political objectives, different media around the globe are using technology to manipulate media coverage and propagate certain political objectives. A vivid case in point is the online medium Azerbaijani Vision which, in its article Is University of Minnesota aware of Mathematics?, distorts, lies about and politicises the historical reality for the advancement of its anti-Armenian goals. Falsification techniques such as (1) presenting forged documents as genuine, (2) manipulating statistical data and figures, (3) using non-existent documents, and (4) neglecting genuine sources - have been used in the history falsification exercise. My assumption is that the blatant falsification of history of any nation and culture should be stopped because it impedes and hinders the development of human society at large. 


\section{Notes:}

1. The term was coined by the French historian Henry Rousso in 1987. He argued that it was necessary to distinguish between legitimate historical revisionism in Holocaust studies and politically motivated denial of the Holocaust, which he termed negationism (in Alain 1998).

2. See about this in detail in the monograph The Use and Abuse of Language in the Legal Domain (Gasparyan, Paronyan, Muradian 2019) Montreal: Arod Books.

3. CHGS (The Center for Holocaust and Genocide Studies 2019) promotes academic research, education and public awareness on the Holocaust, Armenian Genocide and other forms of mass violence. It provides academic programs, scholarly research and inquiries aiming at gaining understanding of the causes and consequences of mass violence, collaborating and sharing expertise and resources with other academic institutions and individuals, providing opportunities for interaction with leading experts in the field, supporting educators by providing online resources, workshops, and seminars, and finally - fighting hatred and ensuring a more peaceful and just world.

\section{References:}

1. Akcam, T. (4 December 2014) Textbooks and the Armenian Genocide in Turkey: Heading Towards 2015. The Armenian Weekly. Available at: $<$ https://armenianweekly.com/2014/12/04/textbooks/> [Accessed October 2019].

2. Alain, F. (1998) The Future of a Negation: Reflections on the Question of Genocide. Lincoln: University of Nebraska Press.

3. Berger, R.J. (2002) Fathoming the Holocaust: A Social Problems Approach. Aldine: Transaction.

4. Bournoutian, G.A. (2009) A Brief History of the Aghuank Region. Michigan: Mazda.

5. Ellul, J. (1973) Propaganda: The Formation of Men's Attitudes. Translated from French by Konrad Kellen \& Jean Lerner. New York: Vintage Books. 
6. Evans, R.J. (2001) Lying About Hitler: History, Holocaust, and the David Irving Trial. NY: Basic Books.

7. Falsification of History. Wikipedia. Available at: <https://yugipedia.com/wiki/Falsification_of_history> [Accessed October 2019].

8. Gasparyan, S.; Paronyan, Sh.; Muradian, G. (2019) The Use and Abuse of Language in the Legal Domain. Montreal: Arod Books.

9. Hewsen, R. (2001) Armenia: A Historical Atlas. Chicago: University of Chicago Press.

10. Historical Negationism. // Wikipedia. Available at: <https://en.wikipedia.org/wiki/Historical_negationism $>$ [Accessed October 2019].

11. Historical Revisionism. // Wikipedia. Available at: <https://en.wikipedia.org/wiki/Historical_revisionism $>$ [Accessed February 2019].

12. Hunter, B. (2017) Education is the State's Greatest Tool for Propaganda. FEE. Available at: <https://fee.org/articles/education-is-the-states-greatesttool-for-propaganda/ $>$ [Accessed September 2019].

13. Is University of Minnesota aware of Mathematics? (15 May 2017) Azerbaijani Vision. Available at: <https:/en.azvision.az/news/65156/armenian-genocide,-the-best-falsigication-of-20th-century.html> [Accessed April 2019].

14. Kevorkian, R.H. and Paboudjian, P.B. (1992) Les Arméniens dans l'Empire Ottoman à la vielle du génocide. Paris: ARHIS.

15. McCarthy, J. (2001) The Population of Ottoman Armenians.// The Armenians in the Late Ottoman Period. Ankara: TBMM/TTK.

16. McPherson, M.J. (1 September 2003) Revisionist Historians. The Newsmagazine of the American Historical Association Perspectives on History.

17. Orwell, G. (1943) Looking Back on the Spanish War. London: New Road.

18. Ottoman Gazette Takvimi Vekâyi (21 July 1920) No. 3909. Available at: <https://fr.images.search.yahoo.com/search/images> [Accessed November 2019].

19. Ravetto, K. (2001) The Unmaking of Fascist Aesthetics. Minessota: University of Minnesota Press. 
20. Redgate, A.E. (1998) The Armenians. GB: Blackwell.

21. Schnirelmann, V. (2001) The Value of the Past: Myths, Identity and Politics in Transcaucasia. Senri Ethnological Studies, 57. Osaka: National Museum of Ethnology.

22. Tall Armenian Tale: 1.5 million genocide victims, lies vs. archives. Available at: <https://www.liveleak.com/view?i=628_1439921546> [Accessed November 2019].

23. University of Minnesota Center for Holocaust \& Genocide Studies. Available at: <https://cla.umn.edu/chgs/about > [Accessed November 2019].

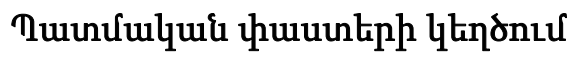

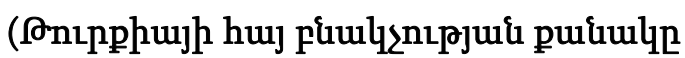 ginuuuquinıpjnıking unuq la htinn)}

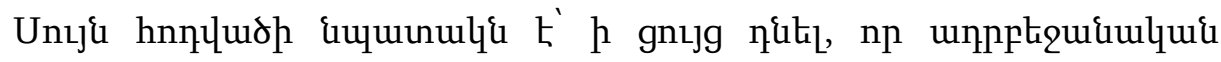

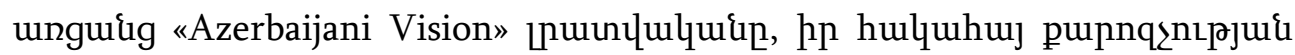

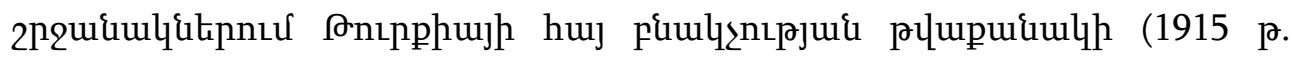

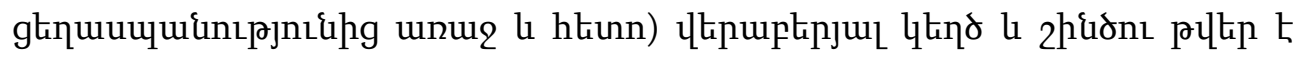

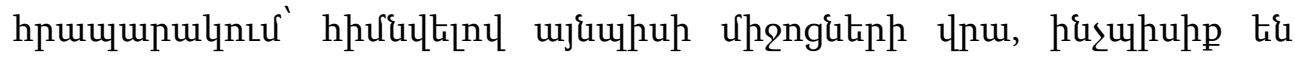

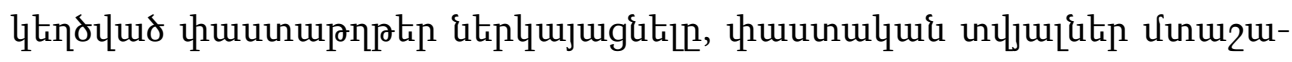

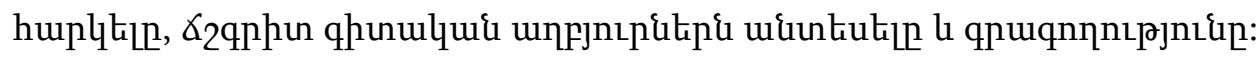

Received by the Editorial Board 14.12.2019

Recommended for publication by the reviewers 01.02.2020

Accepted for print 25.05.2020 